PONTIFÍCIA UNIVERSIDADE CATÓLICA DO RIO DE JANEIRO

\title{
Atitude e percepção do consumidor em relação a smartphones chineses
}

João Borges Miranda

Trabalho de Conclusão de Curso

Centro de CiênCIAS socials - CCS

DEPARTAMENTO DE ADMINISTRAÇÃO

Graduação em Administração de Empresas 
João Borges Miranda

\title{
Atitude e percepção do consumidor em relação a smartphones chineses
}

\author{
Trabalho de Conclusão de Curso
}

Trabalho de Conclusão de Curso, apresentado ao programa de graduação em Administração da PUC-Rio como requisito parcial para a obtenção do título de graduação em Administração.

Orientador(a) : Marcus Wilcox Hemais 


\section{Agradecimentos}

A presente pesquisa não teria sido realizada sem ajuda. Primeiramente, meus agradecimentos vão ao meu orientador. Sem sua orientação e apoio, nada escrito nesse documento existiria. Qualquer aluno seria extremamente privilegiado de tê-lo como professor, orientador ou mentor. Marcus, além de um excelente profissional, é um ser humano excepcional. O Brasil precisa de mais professores como ele.

Agradeço ao apoio de meus amigos e colegas que estiveram comigo ao longo da jornada que é a graduação. As vivências que me proporcionaram me levaram ao ser humano que sou hoje e ao profissional no qual desejo me tornar.

Agradeço aos respondentes das pesquisas realizadas nesse trabalho. Suas contribuições o tornaram realidade.

Ultimamente, agradeço à minha família. Meus pais, Maria Beatriz e Luís Henrique que proporcionaram a mim toda a educação e amor necessários. Tudo que me deram e ainda dão me tornaram o homem que sou hoje. O mesmo pode ser dito de minha avó Emília e minha tia Heloísa. Sempre estiveram do meu lado, fazendo de tudo para que me tornasse a melhor versão de mim mesmo. Agradeço, especialmente, a Giulia Casa Nova. Seu amor, carinho, afeto e companheirismo diários me fazem querer ser uma pessoa melhor. Não poderia desejar ninguém mais excepcional ao meu lado.

Obrigado. 


\section{Resumo}

Miranda, João Borges. Atitude e percepção do consumidor em relação a smartphones chineses. Rio de Janeiro, ano. 53 p. Trabalho de Conclusão de Curso - Departamento de Administração. Pontifícia Universidade Católica do Rio de Janeiro.

Este estudo tem como objetivo analisar a atitude e a percepção do consumidor em relação a smartphones chineses. Para isso, em um primeiro momento, foi realizada uma pesquisa qualitativa junto a dez entrevistados, de modo a selecionar atributos considerados importantes para os consumidores. Posteriormente, fez-se uma pesquisa quantitativa junto a cento e quarenta e sete respondentes, com o intuito de elencar determinados atributos e determinar quais atributos mais influenciam os consumidores na hora de comprar um smartphones. Assim, pôde-se averiguar que atributos como custo $x$ benefício e duração da bateria são mais determinantes que design, por exemplo.

\section{Palavras- chave}

Atitude do consumidor, percepção do consumidor, smartphone, consumidor brasileiro, atributos, China. 


\section{Abstract}

Miranda, João Borges. Consumer attitude and perception towards Chinese smartphones. Rio de Janeiro, 2021. 53 p. Trabalho de Conclusão de Curso

- Departamento de Administração. Pontifícia Universidade Católica do Rio de Janeiro.

This study aims to analyze consumer attitude and perception towards Chinese smartphones. In order to do said analysis, firstly, a qualitative research was carried out with ten interviewees, so that a range of attributes, considered important to the interviewees, could be selected. Then, a quantitative research was carried out with one hundred and forty seven participants, so that the selected range of attributes could be evaluated and, therefore, have determined which attributes have a greater influence on consumers when they have to decide which smartphone to buy. This way, it could be ascertained that attributes such as value for money and battery life are more determining than design, for example.

\section{Key-words}

Consumer attitude, consumer perception, smartphone, Brazilian consumer, attributes, China. 


\section{Sumário}

. Introdução

Objetivo Final 2

Delimitação e foco do estudo 4

Justificativa e relevância do estudo 3

. Referencial Teórico 3

Percepção do consumidor $\quad 4$

$\begin{array}{ll}\text { Atitude do consumidor } & 6\end{array}$

$\begin{array}{ll}\text { Imagem de país de origem } & 9\end{array}$

$\begin{array}{ll}\text {. Metodologia } & 10\end{array}$

$\begin{array}{ll}\text { Tipo de pesquisa } & 11\end{array}$

Fontes de dados $\quad 11$

Coleta de dados $\quad 12$

Tratamento de dados 13

Limitações 13

. Apresentação e análise dos resultados $\quad 14$

$\begin{array}{ll}\text { Descrição e análise dos resultados da pesquisa qualitativa } & 15\end{array}$

$\begin{array}{ll}\text { Descrição e análise dos resultados da pesquisa quantitativa } & 18\end{array}$

\begin{tabular}{ll} 
Conclusões & 22 \\
\hline
\end{tabular}

Implicações práticas do estudo $\quad 24$

Sugestões para estudos futuros $\quad 25$

$\begin{array}{ll}\text { Referências Bibliográficas } & 25\end{array}$

$\begin{array}{ll}\text { Apêndices } & 27\end{array}$

$\begin{array}{ll}\text { Apêndice } 1 & 28\end{array}$

$\begin{array}{ll}\text { Apêndice } 2 & 44\end{array}$ 


\section{Lista de Tabelas}

Tabela 1 - Perfil dos entrevistados

Tabela 2 - Atributos importantes citados pelos respondentes

18

Tabela 3 - Média das respostas da primeira parte do questionário

20

Tabela 4 - Modelo de Fishbein 


\section{Lista de Figuras}

Figura 1 - Xiaomi beats Samsung to become \#1 in India

Figura 2 - Visão geral do processo perceptivo 


\section{Introdução}

É inegável o crescimento das empresas de tecnologia chinesa. Cada vez mais, é possível ver produtos altamente tecnológicos vindos de marcas que eram desconhecidas pelo ocidente até alguns anos atrás. Tais marcas já correspondem a mais de $40 \%$ das compras de smartphones do planeta (TIEYING, 2019). Hoje, essas marcas são uma ameaça à hegemonia de gigantes consolidadas no mercado. Há alguns anos o mais comum era se ver consumidores usando mais frequentemente duas marcas de telefone: Apple e Samsung. Até 2014, elas eram líderes em marketshare no Brasil. Hoje, apesar de a Samsung ainda estar no topo do mercado brasileiro, a segunda mais bem colocada é a Motorola (Lenovo), enquanto a Apple vem tendo seu posto de terceiro lugar ameaçado pela Xiaomi, que está no mercado brasileiro de smartphones somente desde 2018 (STATCOUNTER, 2020). Não é surpresa, portanto, serem encontrados indivíduos andando com Motorola (Lenovo), Xiaomi ou Huawei em seus bolsos. Mas, por que será que isso vem acontecendo? O que tem levado os consumidores a comprarem cada vez mais de marcas chinesas? Empresas de smartphones chinesas vêm tentando mudar a percepção do consumidor acerca de seus produtos nos últimos anos. Um país que outrora era conhecido pela oferta de produtos de baixa qualidade, hoje fabrica alguns dos melhores telefones do mercado. Em 2019, a Huawei foi a segunda empresa do mundo que mais vendeu smartphones, somente atrás da Samsung (TAO e DAI, 2019). Essa maior adesão aos produtos chineses mostra que o estigma criado ao seu redor está caindo.

A ascensão dessas empresas chinesas pode significar uma mudança de paradigma em relação ao tipo de tecnologia que está sendo usada no resto do mundo. Justamente por isso, é preciso aprofundar o conhecimento sobre o motivo de essas marcas estarem conquistando mercados fora da China, a fim de descobrir como o consumidor vê essas companhias e o porquê de ele estar preferindo smartphones chineses. A preferência do consumidor por esses produtos reflete a queda de 
marketshare nos últimos anos de empresas que já estavam em uma situação confortável no mercado há tempos.

A Samsung, entre 2013 e 2018, teve uma queda de quase $10 \%$ do seu marketshare, enquanto a Huawei, no mesmo período, subiu praticamente na mesma proporção (TIEYING, 2019).

Em 2017, a Xiaomi, por exemplo, já havia passado a Samsung na Índia, se tornando a marca de smartphone mais vendida (CANALYS, 2018). Esses dados indicam que os chineses não devem ser subestimados (Figura1).

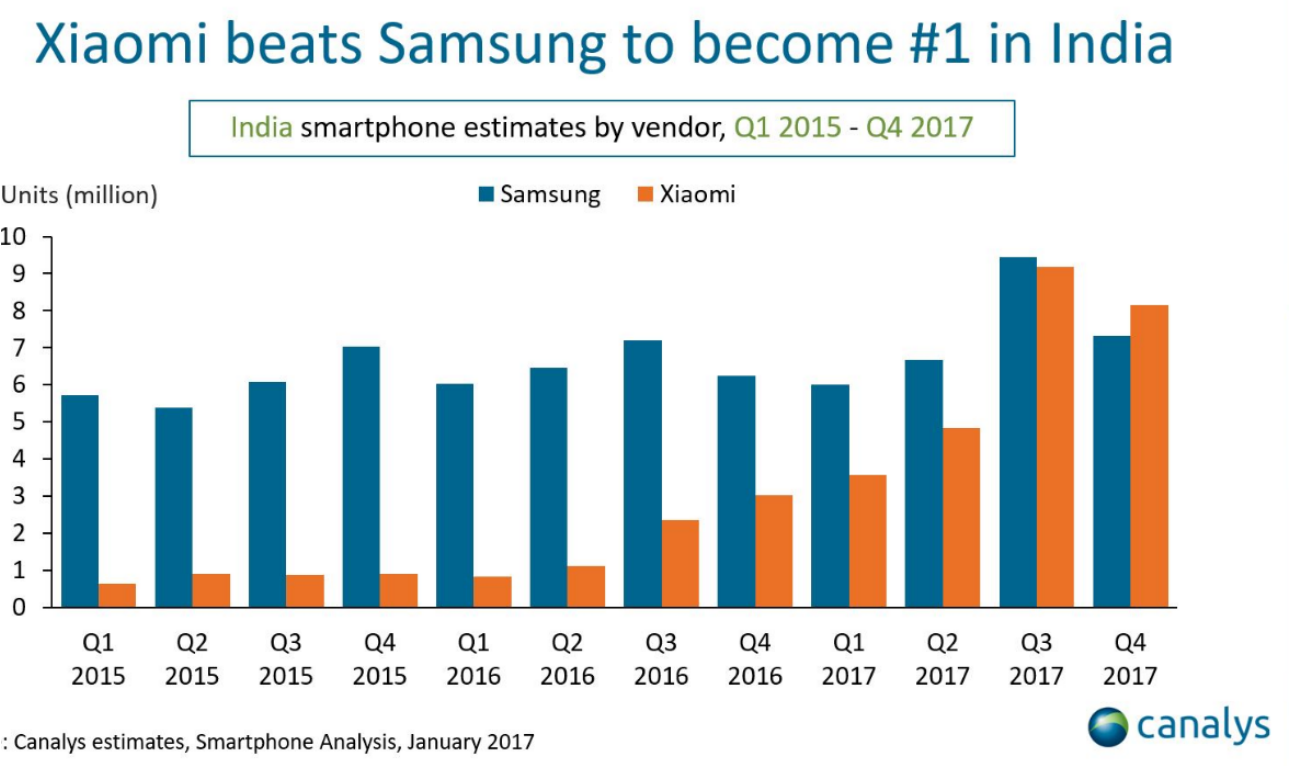

Figura 1 : Xiaomi beats Samsung to become \#1 in India

Levando em conta que as marcas chinesas estão cada vez mais populares, por exemplo, em 2020, o celular mais vendido no Brasil é da Xiaomi (MANSERA, 2020), este trabalho propõe a seguinte questão de pesquisa: qual a atitude e percepção do consumidor brasileiro em relação a smartphones chineses?

\subsection{Objetivo Final}

Esse trabalho tem como objetivo analisar a atitude e percepção do consumidor em relação a smartphones chineses, procurando entender 0 porquê desses produtos conquistarem cada vez mais usuários no Brasil. 


\subsection{Delimitacão e foco do estudo}

O estudo terá como foco analisar o comportamento do consumidor em relação a smartphones. Mas, para a presente pesquisa, será restrita a discussão com base nos conceitos de atitude e percepção do consumidor, pois esses seriam mais em linha com o objetivo aqui buscado.

Embora existam diversas marcas de smartphones sendo vendidas no mundo, originárias de vários países, o presente estudo se delimita a analisar aqueles oferecidos por empresas chinesas.

\subsection{Justificativa e relevância do estudo}

Esse estudo pretende ajudar a compreender como o consumidor de smartphones se comporta, procurando entender mais sobre a atitude e percepção desses indivíduos brasileiros em relação a produtos vindos da China. Portanto, espera-se trazer contribuições tanto de cunho acadêmico, quanto de natureza empresarial.

Para a academia, o presente estudo será importante na medida em que trará mais conhecimento sobre a atitude e percepção do consumidor em relação a produtos de marcas chinesas, um tema ainda pouco analisado pela literatura de marketing.

Já em relação ao âmbito empresarial, permitirá às empresas que concorrem com os chineses saber como eles vêm se diferenciando no mercado global, a partir da ótica de consumidores, e o porquê de estarem cada vez mais populares fora da China, permitindo a elaboração de estratégias de marketing que se adequem aos métodos utilizados pelos chineses. 


\section{Referencial Teórico}

Neste tópico são apresentados e discutidos aspectos conceituais e estudos relacionados ao tema e estudo em investigação e que servirão de base para a análise realizada. Está dividido em três subitens, sendo o primeiro dedicado a discutir a percepção do consumidor, o segundo sobre a atitude do consumidor e o terceiro a respeito de imagem de país de origem.

\subsection{Percepcão do consumidor}

"Percepção é o processo pelo qual as pessoas selecionam, organizam e interpretam sensações (respostas imediatas de receptores sensoriais)" (SOLOMON, 2016, p. 174). Experiências sensoriais como um todo vêm sendo um fator considerável no processo decisório de adquirir um produto. Os consumidores vêm procurando valores hedônicos, ou seja, que vão além da funcionalidade do produto que está sendo adquirido. É comum que o cliente faça pouca diferenciação entre a qualidade dos produtos e, portanto, acabe por ponderar pelas qualidades estéticas (SOLOMON, 2016).

Existem três estágios da percepção: exposição, atenção e interpretação. Esses estágios podem ser entendidos como a maneira que processamos informações. "A exposição ocorre quando um estímulo penetra na gama de receptores sensoriais de uma pessoa." (SOLOMON, 2016, p. 184). O que uma pessoa percebe ou deixa de perceber depende de onde o estímulo se encontra em relação ao limiar sensorial (ponto no qual o estímulo é forte o suficiente para causar um impacto na consciência), podendo estar acima ou abaixo dele. O limiar sensorial de cada um é diferente, o que explica porque algumas pessoas respondem a certos estímulos e outras não. A quantidade mínima de estímulo que uma pessoa consegue detectar é o limiar absoluto, enquanto o limiar diferencial é o ponto no qual detectamos diferenças entre os estímulos. O nome que se 
dá à diferença entre dois estímulos é J.N.D (just noticeable difference) (SOLOMON, 2016).

"A atenção se refere ao grau com que a atividade de processamento é dirigida a um estímulo específico." (SOLOMON, 2016, p. 187). Nós, como seres humanos, não conseguimos processar muitas informações simultaneamente. Por esse motivo, o consumidor pode ser extremamente seletivo em relação a sua atenção. Isso se chama seleção perceptiva. As pessoas só processam alguns estímulos aos quais são expostas, justamente para não ficarem sobrecarregadas.

Para tentar "fisgar" clientes, as empresas precisam que os consumidores estejam em um estado de vigilância perceptiva, ou seja, fiquem atentos a estímulos relacionados às suas necessidades atuais. $O$ oposto da vigilância perceptiva é a defesa perceptiva, quando o consumidor vê somente o que quer e não vê o que não quer. (SOLOMON, 2016).

Um processo relevante quando se discute o estágio da atenção é a adaptação. Ela ocorre quando os consumidores estão muito acostumados com um estímulo e param de dar atenção a ele. Os fatores que levam à adaptação são baixa intensidade, discriminação (estímulos muito simples), alta exposição e baixa relevância (SOLOMON, 2016).

Anúncios visualmente complexos possuem maior chance de capturar atenção. Para capturar atenção, as mensagens devem gerar contraste, que pode ser criado por tamanho, cor, posição e novidade (estímulos que aparecem de um modo ou em lugares inesperados). (SOLOMON, 2016).

"A interpretação se refere a significados que atribuímos a estímulos sensoriais. Assim como as pessoas são diferentes com relação aos estímulos que recebem, os significados que atribuem a esses estímulos também varia." (SOLOMON, 2016, p. 193). Como um estímulo será interpretado depende da sua relação com outros eventos, imagens memorizadas ou sensações (SOLOMON, 2016).

É um hábito comum (e involuntário) que associemos sensações novas com outras já guardadas em nossas memórias. Esse processo involuntário se baseia na psicologia gestalt, que defende que as pessoas interpretam significados com base em vários estímulos juntos, e não apenas um. 
A psicologia gestalt trabalha com alguns princípios ligados a como nosso cérebro organiza os estímulos: o princípio da complementação, o princípio da similaridade e o princípio figura-fundo (SOLOMON, 2016).

- "Princípio da complementação - as pessoas tendem a perceber uma figura incompleta como se fosse completa. Isto é, tendemos a preencher lacunas com base em nossas experiências prévias." (SOLOMON, 2016, p. 196).

- "Princípio da similaridade - os consumidores tendem a agrupar objetos que compartilham características físicas semelhantes." (SOLOMON, 2016, p. 196).

- "Princípio figura-fundo - uma parte do estímulo predominará (uma figura central) e outras partes se perderão no segundo plano." (SOLOMON, 2016, p. 197).

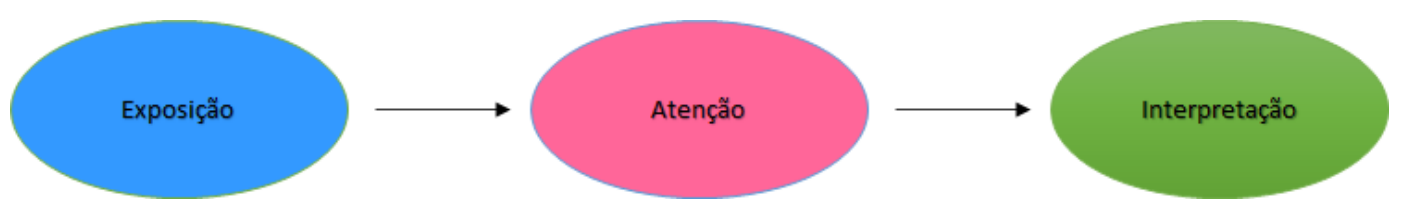

Figura 2: Visão geral do processo perceptivo.

Fonte: SOLOMON (2016). Comportamento do consumidor: Comprando, Possuindo e Sendo (p. 184). Porto Alegre: Bookman.

\section{2. $\quad$ Atitude do consumidor}

"Atitude é uma avaliação duradoura e genérica sobre pessoas (incluindo nós mesmos), objetos, anúncios ou problemas." (SOLOMON, 2016, p. 301). Uma atitude é formada por três componentes: afeto, comportamento e cognição. "O afeto diz respeito a como um consumidor se sente em relação a um objeto de atitude. $O$ comportamento se refere às suas intenções de tomar uma atitude quanto a isso. A cognição é o que ele acredita ser verdadeiro quanto ao objeto de atitude." (SOLOMON, 2016, p. 302). Esses três componentes juntos formam o modelo ABC. Segundo Solomon (2016), ele é usado para enfatizar as inter-relações entre conhecer, sentir e fazer. 
Como nem toda atitude é formada da mesma maneira, devemos saber distingui-las. Cada consumidor tem um comprometimento diferente com a atitude, que depende do nível de envolvimento com o objeto de atitude. Existem três níveis de comprometimento:

- Condescendência - na condescendência, a atitude é formada porque pode nos ajudar a obter recompensas ou evitar punições. É considerada extremamente superficial, visto que muda quando outras pessoas deixam de monitorar o comportamento do indivíduo.

- Identificação - a identificação acontece quando a atitude é formada para que nos adequemos a uma pessoa ou grupo específico. É comum vermos propagandas que mostram as consequências sociais de certas escolhas. É justamente nisso que se baseia a identificação.

- Internalização - na internalização, aquelas atitudes que já estão profundamente enraizadas em nosso subconsciente passam a fazer parte dos nossos valores e se tornam quase impossíveis de serem alteradas, pois passamos a considerá-las, assim como nossos valores, extremamente importantes.

"De acordo com o princípio da coerência cognitiva, valorizamos a conformidade entre nossos pensamentos, sentimentos e comportamentos e somos motivados a manter a homogeneidade entre esses elementos." (SOLOMON, 2016, p. 306). Isso significa que podemos mudar nossos pensamentos, sentimentos e comportamentos se acharmos que eles podem ficar mais coerentes com outras experiências.

Segundo essa teoria, quando há incompatibilidades entre atitudes ou comportamentos, o indivíduo age para que a incoerência seja resolvida, o que pode ser feito tanto mudando a atitude quanto o comportamento, dando a possibilidade de a coerência ser restaurada. É comum passarmos por situações nas quais há conflitos entre atitudes quanto a produtos ou serviços e o que de fato fazemos ou compramos (SOLOMON, 2016).

Segundo a teoria da dissonância cognitiva, o que nos motiva a abrandar qualquer sentimento negativo trazido pela dissonância nos faz 
encontrar uma congruência entre sentimentos e crenças. Essa teoria foca em situações nas quais dois elementos cognitivos conflitam, sendo que um elemento cognitivo pode ser uma crença, um comportamento ou até uma observação do ambiente no qual a pessoa está inserida. Existe mais pressão para que a dissonância seja reduzida em situações nas quais há alto envolvimento e pressão para que as incoerências sejam reduzidas (SOLOMON, 2016).

A teoria da dissonância ajuda a compreender o porquê de avaliações sobre um produto crescerem em números após a compra. Com frequência consumidores procuram respaldo para suas decisões, como se devessem justificá-la. Justamente por isso que as companhias deveriam fornecer algum tipo de reforço pós-compra, para reforçar a decisão tomada (SOLOMON, 2016).

"Como as atitudes são muito complexas, os pesquisadores de marketing podem usar o modelo de atitude multiatributo para compreendêlas. Esse tipo de modelo pressupõe que a atitude de um consumidor em relação a um objeto de atitude $\left(A_{0}\right)$ depende das crenças que ele tem com respeito a alguns ou muitos dos atributos do objeto. Quando utilizamos um modelo multiatributo, presumimos que podemos identificar essas crenças específicas e associá-las para gerar uma avaliação da atitude geral do consumidor." (SOLOMON, 2016, p. 312).

Os modelos multiatributo são formados por três elementos: atributos, crenças e pesos de importância. Atributos são características do objeto de atributo que está sendo analisado. Os pesquisadores de marketing tentam identificar os atributos que a maioria dos consumidores usa quando estes avaliam o objeto de atributo. Crenças podem ser consideradas cognições sobre o objeto de atributo. Uma medida de crença irá avaliar até que ponto o consumidor irá perceber que uma marca tem um determinado atributo. Pesos de importância refletem o quão prioritário é um atributo para o consumidor. Embora muitas pessoas considerem um único objeto de atributo como uma série de atributos, é provável que alguns sejam mais importantes do que outros. Além disso, é comum que esses pesos se alterem de consumidor para consumidor (SOLOMON, 2016). 


\subsection{Imagem de país de origem}

"Um dos fatos da vida em marketing global é que percepções e atitudes em relação a certos países frequentemente se estendem a produtos e marcas que se originam desses países. Tais percepções contribuem para o chamado efeito de país de origem; os países se tornam parte da imagem de uma marca e contribuem para brand equity." (GREEN e KEEGAN, 2016, p. 340)

É curioso como indivíduos prontamente julgam certos produtos ou serviços a partir de pré-julgamentos existentes a respeito dos países de onde esses produtos e serviços se originam. Pode-se dizer que esses julgamentos são muito injustos, uma vez que, no mundo globalizado, é comum que os produtos sejam produzidos em um país, desenhados em outro e promovidos por um terceiro (HESLOP e PAPADOPOULOS, 1993).

Considerando-se que a imagem de país de origem afeta a atitude dos consumidores acerca de produtos, é importante destacar que essas atitudes não necessariamente são generalizáveis entre os diversos produtos de um mesmo país. A visão que se tem do café brasileiro, por exemplo, no mercado internacional não necessariamente é a mesma dos nossos perfumes.

Como, por conta da globalização, produtos podem ser feitos praticamente em qualquer lugar e suas características centrais vêm sendo cada vez mais padronizadas, uma alternativa para o marketing diferenciar os diversos concorrentes é apelar para a (boa) imagem que determinado país tem (HESLOP e PAPADOPOULOS, 2002).

$\mathrm{Na}$ era em que vivemos, informação é provavelmente o recurso mais abundante. Pessoas são saturadas todos os dias com quantidades tão exorbitantes de informações que simplesmente não são possíveis de serem processadas. Um recurso que é utilizado para facilitar esse processo é reduzir o produto ou serviço ao seu país de origem (HESLOP e PAPADOPOULOS, 2002). 
A imagem de país de origem é um estereótipo que afeta não só potenciais consumidores, como também turistas, indústrias e investidores (quando consideram se expandir para outros países) e inclusive governos (HESLOP e PAPADOPOULOS, 2002).

É curioso como quanto pior é a imagem de um país, mais os consumidores esperam que os produtos desse lugar sejam baratos, em comparação a um produto idêntico de um país com uma imagem melhor. Isso explica, por exemplo, o porquê de muitas empresas anunciarem que seus produtos são desenhados ou idealizados nos países de origem das marcas, em contrapartida aos países onde foram fabricados (HESLOP e PAPADOPOULOS, 2002).

Consumidores industriais tendem a perceber o design de produtos como melhores em países desenvolvidos do que em países em desenvolvimento, enquanto o contrário é visto para produção e montagem de bens. Além disso, quanto mais complexo é o produto, maior é a importância percebida do design (HESLOP e PAPADOPOULOS, 2002).

É curioso como a percepção que um indivíduo tem de um país pode afetar sua percepção geral de uma classe de produtos, independentemente da percepção global existente acerca dessa classe de produtos (HESLOP e PAPADOPOULOS, 2002). Por exemplo, há uma boa percepção global acerca de perfumes franceses, enquanto o mesmo não pode ser dito de perfumes alemães. Porém, se uma pessoa tem uma percepção particularmente boa da Alemanha, sua percepção acerca de perfumes alemães será melhor do que a global.

\section{$3 \quad$ Metodologia}

O presente capítulo aborda a metodologia utilizada na pesquisa, evidenciando qual é o tipo de pesquisa, a fonte de dados, como foram 
realizadas a coleta e análise de dados e, por fim, as limitações da metodologia.

\section{1. $\quad$ Tipo de pesquisa}

Essa pesquisa tem caráter exploratório e descritivo. Ela é exploratória porque tem como objetivo examinar um problema ou uma situação para se obter conhecimento e compreensão e formula o problema com mais precisão, desenvolve hipóteses e estabelece prioridades para pesquisas adicionais (MALHOTRA, 2011).

A pesquisa também tem caráter descritivo porque tem como objetivo principal a descrição de características ou funções de um mercado. Além disso, outros objetivos desse tipo de pesquisa são desenvolver o perfil do mercado-alvo e determinar a relação entre o uso do produto e a percepção das características desse produto (MALHOTRA, 2011).

\section{2. $\quad$ Fontes de dados}

A pesquisa contou com dois tipos de dados, tanto os qualitativos, quanto os quantitativos. Os dados qualitativos foram originários de entrevistas com 10 usuários de smartphones de marcas chinesas. Os entrevistados foram escolhidos por conveniência e o seu perfil foi definido buscando diversidade, de maneira a tornar as respostas o menos enviesadas possível. A Tabela 1 evidencia os perfis dos entrevistados (por consenso entre entrevistador e entrevistados, os nomes foram ocultados por questão de privacidade). 


\begin{tabular}{|c|c|c|}
\hline \multicolumn{2}{|c|}{ Entrevistado Idade } & Profissão \\
\hline 1 & 30 & Engenheiro \\
\hline 2 & 26 & Estudante de design \\
\hline 3 & 26 & Economista \\
\hline 4 & 50 & Professor \\
\hline 5 & 26 & Administrador \\
\hline 6 & 41 & Diarista \\
\hline 7 & 24 & Auxiliar de escritório \\
\hline 8 & 23 & Estudante de jornalismo \\
\hline 9 & 56 & Professor \\
\hline 10 & 32 & Advogado \\
\hline
\end{tabular}

Fonte: Elaboração própria

Em relação aos dados quantitativos, foram obtidas 147 respostas a partir de um questionário disponível na plataforma Google Forms a contatos do pesquisador. A pesquisa qualitativa se restringiu somente a usuários de smartphones de marcas chinesas, enquanto a quantitativa abrangeu um público maior, uma vez que havia a intenção de avaliar as opiniões de usuários de marcas não chinesas acerca de telefones chineses.

O perfil dos entrevistados da pesquisa quantitativa é exposto no capítulo de análise dos dados.

\subsection{Coleta de dados}

A coleta de dados foi feita por meio de duas pesquisas, uma qualitativa e uma quantitativa. O principal objetivo da pesquisa qualitativa era avaliar unicamente as opiniões dos usuários acerca de seus smartphones de marcas chinesas, levando em consideração suas percepções, atitudes e imagens de país de origem (no caso, a imagem que se tem a partir de produtos de marcas chinesas ou vindos da China). Foi a partir das respostas dessa etapa que os atributos mais relevantes dos smartphones foram levantados. Essa pesquisa foi realizada por meio de entrevistas (feitas presencialmente e via aplicativo de mensagens) em profundidade com os entrevistados, a partir de um roteiro de entrevistas (disponível no Apêndice 1).

A pesquisa quantitativa foi realizada para que se pudesse ser feito 0 modelo de Fishbein, de forma que foram mensuradas as atitudes de 
consumidores sobre três marcas (sendo uma delas da China). A maior preocupação desta etapa foi conseguir o maior número de indivíduos possível para que fosse possível construir uma análise suficientemente densa em relação aos atributos avaliados pelos usuários em suas respostas. Um questionário (disponível no Apêndice 2) foi elaborado e hospedado na plataforma Google Forms. O link do questionário foi enviado para conhecidos do pesquisador, que repassaram para os seus próprios contatos. Após três semanas de o questionário estar disponível online, encerrou-se a coleta de dados, pois se julgou que já se havia alcançado um número suficiente de respondentes.

\section{4. $\quad$ Tratamento de dados}

Todas as entrevistas da etapa qualitativa foram transcritas, compiladas e transformadas em um único documento de Microsoft Word, de maneira a facilitar a comparação de respostas entre os entrevistados. Após devida comparação, pôde-se encontrar algumas semelhanças e diferenças entre as opiniões dos entrevistados. Essas semelhanças permitiram elencar determinados atributos mais relevantes para os consumidores na hora de se escolher um smartphone.

$\mathrm{Na}$ etapa quantitativa, as informações foram levantadas pela plataforma Google Forms. A partir dos resultados alcançados, fez-se uma média ponderada das respostas referentes aos atributos. Essa média permitiu o cálculo dos scores de atitude, de acordo com o Modelo de Múltiplos Atributos de Fishbein.

\subsection{Limitacões}

Embora todas as entrevistas tenham sido feitas com pessoas reais e sempre buscando perfis distintos, com o objetivo de trazer visões e opiniões únicas, o fato de os participantes serem em maioria pessoas conhecidas e próximas pode resultar em viés. Segundo Kates (1998), como o número de entrevistados de uma pesquisa qualitativa acaba sendo pequeno (representando uma escala ínfima da sociedade), as 
opiniões desse grupo não necessariamente representam a realidade do todo e, portanto, não seria correto ou preciso aplicar os resultados de uma pequena porção de pessoas à maioria.

Em relação à etapa quantitativa, algumas das possíveis limitações seriam a exclusão de indivíduos analfabetos e semianalfabetos (o que implica na deformação de resultados), impossibilidade de auxiliar o participante e a falta de garantia de que todos os respondentes preencheram 0 questionário corretamente, incorrendo numa diminuição da amostra em questão (GIL, 2008). 


\section{$4 \quad$ Apresentação e análise dos resultados}

Este capítulo, organizado em duas seções, apresenta, discute e analisa os principais resultados alcançados pela pesquisa.

\subsection{Descrição e análise dos resultados da pesquisa qualitativa}

A partir das respostas coletadas na etapa qualitativa, verificou-se alguns pontos de interseção entre as contribuições dos participantes. Pôdese notar, ao conversar com os entrevistados, que os atributos mais levados em conta ao se comprar um telefone celular são a qualidade da câmera, a duração da bateria e o custo $x$ benefício.

No Brasil, como bons smartphones tendem a ser caros, em razão de fatores como taxa de câmbio do dólar alta e tecnologias mais avançadas (VANI, 2020), observa-se que o atributo que mais é levado em conta na hora de comprar um telefone celular é o custo $\mathrm{x}$ benefício. Os consumidores tendem a achar que um telefone que custe entre $R \$ 1500,00$ e $R \$ 2000,00$ já está no limite do aceitável e simplesmente consideram que qualquer aparelho acima deste limiar não vale à pena. Um comentário que sintetiza bem isso é o do Entrevistado 5. Segundo ele, "abaixo de $R \$ 750,00$ é barato para qualquer nível e acima de $\mathrm{R} \$ 2.000,00$ é caro para qualquer nível (nenhum celular entrega o suficiente para mais que isso valer a pena)". Essa crença, segundo Solomon (2016), seria uma cognição, de acordo com o Modelo ABC de Atitude, em relação aos smartphones. Isso significa dizer que os consumidores creem ser verdadeiro que pagar acima de $R \$ 2000,00$ por um telefone não é algo aceitável. Pode-se dizer, também, que os consumidores entrevistados nessa pesquisa têm um nível de comprometimento internalizado em relação à atitude que se tem em relação ao preço de um telefone celular. De acordo com Solomon (2016), em um 
nível de comprometimento internalizado as atitudes já estão enraizadas nos valores do indivíduo e, portanto, são tão importantes quanto ele. A partir das respostas dos participantes, entende-se que é até "ultrajante" pagar uma quantia tão alta por um smartphone. Isso se evidencia, por exemplo, nas respostas dos entrevistados 1 e 2 quando dizem, respectivamente: "Eu sempre comparo com a qualidade dele, então complica, mas acho que abaixo de $R \$ 800,00$ é incontestavelmente barato e acima de $R \$ 2000,00$ é incontestavelmente caro." e "Eu vejo por comparativo. Mas pra mim qualquer celular é caro, qualquer celular acima de $R \$ 1.000,00$ pra mim vai ser caro. Acima de $R \$ 2.000,00$ eu já começo a me perguntar se realmente vale a pena, mesmo se ele for bom. Acima de $\mathrm{R} \$ 3.000,00$ é não.".

Outro atributo bastante mencionado é a qualidade da câmera. Buscase bastante celulares com tecnologia capaz de capturar imagens fiéis à realidade, sem grandes distorções. Em geral, percebe-se que os entrevistados julgam suas câmeras entre medianas e boas.

Uma terceira questão importante, apontada pelos entrevistados, é a duração da bateria. Os usuários buscam telefones com baterias de longa duração, de maneira a durar um dia inteiro com uma única carga. Esse prérequisito pode ser considerado compreensível, uma vez que muitas pessoas saem de casa cedo para trabalhar e voltam tarde e às vezes não têm oportunidade de recarregar seus aparelhos ao longo do dia.

Também foi perguntado aos entrevistados o que acham do design de seus aparelhos. É particularmente interessante entender até que ponto os consumidores consideram o design como um atributo importante porque Solomon (2016), ao falar sobre o conceito de percepção, diz que é comum que os consumidores façam pouca diferenciação entre as qualidades de um produto e passem a procurar valores hedônicos ao comprar um item. Desse modo, a intenção nessa etapa da pesquisa era entender o quanto o público leva em consideração as características estéticas de um smartphone ao comprar um. Em geral, o que se descobriu é que os entrevistados acham que os telefones celulares são muito parecidos e, portanto, a parte estética acaba sendo um fator de pouca relevância. Isso se reflete, por exemplo, no comentário do Entrevistado 8. De acordo com ele, "como, hoje em dia, todos usamos capas de proteção nos celulares, 
acabo não prestando muita atenção nessa parte estética. Não me lembro de ter comprado um telefone por isso." No máximo, o que pode gerar algum grau de importância, nesse quesito, é a cor do telefone. No entanto, como existe uma grande variedade de cores, muitas vezes para o mesmo modelo, essa questão não costuma ser um grande problema.

Provavelmente, como diversos usuários não enxergam grandes variações de designs entre os diferentes telefones do mercado, companhias apostam em lançar diferentes cores para um mesmo aparelho. Enquanto o design em si pode não causar tanto impacto, uma cor diferente pode estar acima do limiar sensorial, conseguindo fazer com que o cliente passe pelos três estágios da percepção que Solomon (2016) discute.

Quando perguntados sobre a qualidade do áudio de seus telefones, os participantes os julgaram medianos. Em geral, o consumidor se preocupa com sons claros, potentes, sem ruídos e com poucas distorções em relação à realidade.

A etapa qualitativa também buscou compreender como os participantes se sentiam em relação a produtos vindos da China. Pôde-se observar opiniões bem divididas. Alguns gostam, outros sentem desconfiança e uma outra parcela não se importa. No entanto, ficou claro que a maioria diria que seus aparelhos são bons, tem opiniões favoráveis a marcas de telefones chineses e, diante de suas experiências, recomendariam esses smartphones a terceiros. A seção de perguntas referentes ao fato de os smartphones serem chineses buscou entender se ocorria o Efeito País de Origem (GREEN; KEEGAN, 2016) em relação a esses produtos, ou seja, se as percepções e atitudes que as pessoas têm em relação à China se estendem aos produtos de marcas chinesas. Durante muito tempo (e isso ainda ocorre, em certo grau), produtos vindos da China eram sinônimos de baixa qualidade ou falsificações. Hoje, ainda existe bastante desconfiança em relação a produtos vindos dos chineses, como pode ser visto nas respostas dos entrevistados 9 e 10. Quando perguntados quais sentimentos tinham em relação a produtos vindos da China, ambos tiveram a mesma resposta: "Desconfiança". Em setembro de 2021, o governo da Lituânia recomendou à população que se livrasse de aparelhos de marcas chinesas porque os usuários estavam sujeitos a 
censuras e falhas de segurança (BBC News Mundo, 2021). Isso ilustra bem as respostas dos entrevistados 9 e 10 na pesquisa qualitativa em relação a produtos vindos da China.

Quando perguntados a que marca(s) os entrevistados associavam à palavra "smartphone", a única marca que apareceu em todas as respostas foi Motorola (Lenovo), justamente uma marca, agora, chinesa. Outras respostas bastante recorrentes foram Apple (americana), Samsung (sulcoreana) e Xiaomi, também chinesa.

Outro ponto recorrente entre as respostas dos entrevistados foi qual era o fator diferencial entre os telefones deles dos de outras marcas. Em geral, todos julgam o preço/custo $x$ benefício como sendo o fator determinante.

Na Tabela 2, são listados os principais atributos que os respondentes consideraram importantes em um smartphone.

Tabela 2 - Atributos importantes citados pelos respondentes

\begin{tabular}{|c|}
\hline Atributos importantes citados pelos respondentes \\
\hline Câmera de qualidade \\
\hline Bateria de longa duração \\
\hline Armazenamento bom \\
\hline Processador bom \\
\hline Tela de alta resolução \\
\hline Responsividade \\
\hline Boa compatibilidade de aplicativos \\
\hline Preço/Custo $x$ Benefício \\
\hline
\end{tabular}

Fonte: Elaboração própria

\subsection{Descricão e análise dos resultados da pesquisa quantitativa}

A pesquisa quantitativa, realizada com um grupo maior de entrevistados, foi feita com o objetivo de compreender de maneira mais geral as atitudes dos usuários em relação aos smartphones chineses, sempre comparando com marcas bem disseminadas no mercado brasileiro. Para a pesquisa, foram selecionadas as marcas Apple (mais especificamente o iPhone), Samsung e Xiaomi (ou outra marca chinesa de 
conhecimento do respondente, visto que a intenção era saber a opinião do público a respeito de telefones chineses, e não uma marca chinesa específica).

Dentre os atributos discutidos na etapa qualitativa, foram selecionados para a etapa quantitativa custo $\mathrm{x}$ benefício, qualidade da câmera, qualidade da bateria e design. Embora design não tenha sido um dos atributos mais relevantes para os respondentes da etapa qualitativa, ele foi relacionado para a segunda etapa porque, segundo Lei Jun, CEO e cofundador da Xiaomi, "se houver melhora constante da qualidade e do design, consumidores estarão mais dispostos a pagar pelos produtos" (Jun, Lei apud Tao \& Dai, 2019, tradução nossa). Diante disso, é interessante comparar a estratégia da empresa com a realidade do mercado brasileiro. Segundo Heslop e Papadopoulous (2002), consumidores tendem a perceber o design de produtos como melhores em países desenvolvidos do que em países em desenvolvimento, além de que quanto mais complexo é o produto, maior é a importância percebida do design. Essa talvez seja uma explicação do porquê de a Xiaomi, por exemplo, achar que investir no design de seus aparelhos seja tão importante.

Essa etapa contou com 147 respondentes. Desses, 74,8\% não possuem um telefone de marca chinesa, $18,4 \%$ possuem e $6,8 \%$ não souberam responder.

A primeira parte do questionário contou com seis perguntas, das quais quatro se referiam às atitudes dos respondentes em relação aos atributos de seus smartphones. Suas respostas eram dadas a partir de uma escala de 10 pontos, sendo possível, assim, calcular as médias das respostas, conforme mostra a Tabela 3.

Tabela 3 - Média das respostas da primeira parte do questionário

\begin{tabular}{|l|c|}
\hline \multicolumn{1}{|c|}{ Pergunta } & Média \\
\hline Em relação ao seu smartphone, o que você acha da qualidade da sua câmera? & 8 \\
\hline Em relação ao seu smartphone, o que você acha da duração da bateria? & 7 \\
\hline Em relação ao seu smartphone, o que você acha do seu design? & 9 \\
\hline Em relação ao seu smartphone, o que você acha do seu Custo x Benefício? & 8 \\
\hline
\end{tabular}

Fonte: Elaboração própria 
As possíveis conclusões que se pode tirar a partir desses dados é que, em geral, os usuários estão satisfeitos com os atributos de seus telefones. No entanto, tendo como base as respostas da pesquisa qualitativa e o modelo de Fishbein - que é mostrado a seguir -, percebe-se que o atributo design, apesar de ter tido a média mais alta, é aquele com o qual os usuários menos se importam. Diante disso, infere-se que os atributos com notas inferiores são aqueles que os respondentes acreditam que mais precisam melhorar e, consequentemente, mais Ihe incomodam em seus aparelhos.

De modo que o modelo de Fishbein pudesse ser feito, foram considerados dois grupos de respostas. Primeiramente, os respondentes elencaram os atributos em grau de importância (pergunta 6 do Apêndice 2). Nessa etapa, os participantes davam pesos a cada atributo. Esses pesos foram posteriormente distribuídos entre os atributos e foi feita uma média ponderada. Essa média corresponde ao peso que cada atributo tem na Tabela 4. Em seguida, foram analisadas as respostas das perguntas que comparavam atributos entre marcas de smartphones (perguntas 7, 8, $9 \mathrm{e}$ 10 do Apêndice 2). Nessas perguntas, os usuários classificaram os atributos das três marcas selecionadas em uma escala de 1 a 10 , com 1 sendo a nota mais baixa e 10 a mais alta. Não era relevante para a pesquisa se os respondentes já haviam tido ou não experiências prévias com as marcas, apenas que dessem suas opiniões sobre elas. Dessa forma, compreende-se melhor as atitudes dos usuários em relação às marcas analisadas por essa pesquisa.

Finalmente, os pesos dos atributos foram multiplicados pelos valores de cada atributo por marca (conforme opiniões dos respondentes) e os produtos foram somados ao final. O resultado disso é o score de atitude de cada marca. A partir das respostas coletadas dos 147 participantes, chegou-se aos scores de atitude mostrados na Tabela 4: 
Tabela 4 - Modelo de Fishbein

\begin{tabular}{|l|c|c|c|c|}
\cline { 3 - 5 } \multicolumn{2}{c|}{} & \multicolumn{3}{c|}{ Marcas } \\
\hline \multicolumn{1}{|c|}{ Atributo } & Peso & iPhone & Samsung & Xia omi ou outra chinesa \\
\hline Qualidade da câmera & 3,09 & 8,57 & 7,78 & 6,80 \\
\hline Duração da bateria & 3,44 & 6,27 & 7,28 & 7,33 \\
\hline Design & 2,52 & 8,16 & 7,81 & 6,75 \\
\hline Custo x benefício & 3,49 & 4,80 & 6,84 & 7,37 \\
\hline \multicolumn{2}{|c|}{ Score de atitude } & 85,43 & 92,68 & 89,02 \\
\hline
\end{tabular}

Fonte: Elaboração própria

Conforme pode ser visto na Tabela 4, a maior pontuação geral foi a da Samsung, seguida por Xiaomi e, finalmente, iPhone. Entretanto, algumas marcas tiveram resultados melhores do que outras em algum atributo específico. A Samsung, por exemplo, apesar de ter a melhor pontuação geral, curiosamente não teve a melhor pontuação em nenhum atributo. No entanto, teve bom desempenho em praticamente todos, o que Ihe garantiu o melhor score. Diante disso, o que se entende é que a Samsung entrega smartphones com boas câmeras fotográficas, uma bateria com boa duração e um design agradável por um preço razoável.

O iPhone, por sua vez, nas opiniões dos respondentes, tem a melhor qualidade de câmera e o melhor design. Apesar disso, como foi discutido anteriormente, o design não é um fator tão importante quanto os outros atributos para os consumidores e, portanto, a alta pontuação que recebeu acaba afetando pouco o seu score final. Ainda em relação ao iPhone, sua duração de bateria foi considerada mediana e seu custo $x$ benefício obteve uma pontuação baixa. Como o custo x benefício é o atributo com o maior peso, compreende-se porque o iPhone teve o menor score entre as três marcas analisadas. Com isso, entende-se que os smartphones da Apple têm excelentes câmeras fotográficas e designs extremamente satisfatórios, mas com baterias apenas razoáveis. Apesar disso, o custo envolvido na aquisição de um iPhone não compensa tais atributos.

A Xiaomi, embora tenha a qualidade da câmera e o design considerados medianos, teve bom desempenho na duração da bateria e no custo x benefício, os atributos com os maiores pesos. Com isso, garantiu o segundo melhor score geral. Conclui-se, a partir das atitudes dos 
respondentes, que os smartphones chineses têm designs e câmeras razoáveis, com boa duração de bateria e um bom custo benefício. 


\section{Conclusões}

Esta pesquisa foi feita com o objetivo de analisar e compreender as atitudes e percepções dos consumidores em relação a smartphones chineses. Para tornar o estudo possível, foram realizadas duas pesquisas, uma qualitativa e uma quantitativa. A etapa qualitativa foi realizada apenas com usuários de smartphones de marcas chinesas, enquanto a quantitativa englobou usuários de diversas marcas de múltiplas origens.

A partir das pesquisas feitas, o que se conclui é que smartphones de marcas chinesas estão ganhando cada vez mais espaço no mercado nacional e a atitude e a percepção do consumidor brasileiro se mostram cada vez mais positivas em relação a esses produtos. Aparelhos que outrora geravam desconfiança entre os consumidores (e ainda geram, em certo grau, conforme respostas da pesquisa qualitativa) agora conquistam espaço de maneira promissora entre os brasileiros. Entende-se, a partir dos dados coletados pelo presente estudo, que a antiga imagem de país de origem que a China transparecia (a ideia de que produtos vindos deste país eram de baixa qualidade ou falsificados) vem ficando de lado, dando lugar a uma China altamente tecnológica e capaz de competir com grandes rivais.

Ainda que Lei Jun, CEO e cofundador da Xiaomi, pense que o design seja um fator primordial para conquistar consumidores, isso não parece se aplicar à realidade brasileira. Pode-se afirmar que o fator que mais influencia os brasileiros na hora de comprar um telefone celular é o custo $x$ benefício do aparelho e, segundo a pesquisa quantitativa conduzida pelo presente estudo, isso a Xiaomi e outras marcas chinesas vêm entregando de maneira satisfatória.

Outra possível conclusão a partir do presente estudo é que os atributos mais valorizados de um smartphone por um grupo de usuários certamente variam dependendo da situação em que esses usuários se encontram. Muito provavelmente, enquanto o custo $\mathrm{x}$ benefício tem um 
peso maior para um consumidor brasileiro, o design tem um peso maior para um consumidor americano visto que, enquanto um indivíduo no Rio de Janeiro precisaria trabalhar 316 horas para adquirir um iPhone em 2018, um nova-iorquino precisaria de apenas 54,1 horas para adquirir o mesmo aparelho (SZMIGIERA, 2021). É possível (e provável) que a afirmação de Lei Jun se baseie em uma estratégia global. No entanto, deve-se sempre analisar as especificidades de cada mercado antes de tomar uma decisão a respeito de em que se deve investir. Quando uma empresa atua em locais diversos e lida com culturas, gostos e conjunturas diversas, é necessário saber ser resiliente e se adaptar a cada situação.

\subsection{Implicacões práticas do estudo}

Alguns atributos importantes para um mercado podem não ser tão importantes para outro. Recomenda-se àquelas empresas que desejam aumentar seu marketshare no mercado brasileiro entregar produtos de qualidade a preços mais acessíveis. Fatores como design, por exemplo, pouco influenciam se o consumidor não é capaz de adquirir um aparelho minimamente bom por questões financeiras.

Ademais, o fato de o Brasil estar há anos em uma situação econômica delicada certamente influencia na capacidade do cidadão médio em adquirir produtos industrializados, como smartphones, de alta qualidade. Seria interessante que as marcas desses produtos considerassem mais o poder de compra de seus possíveis futuros clientes. Isso as tornaria mais competitivas e daria ao consumidor uma gama maior de opções.

Apesar de design, quando comparado a preço, não ser um fator tão relevante para os brasileiros, não significa que as companhias de smartphones devam deixar de investir em aspectos estéticos. No Brasil, produtos industriais, como telefones celulares, ainda são indicativos de status e certamente um aparelho esteticamente agradável é mais capaz de agradar ao consumidor que um celular cuja fabricante não se preocupa muito com o design. Afinal, se o consumidor considerar que atributos como preço, qualidade da câmera e duração da bateria são muito similares entre 
suas opções, é muito provável que ele acabe por ponderar entre qual aparelho é "mais bonito" ou lhe passa uma sensação de "status maior".

Algumas estratégias que marcas de smartphones vêm utilizando para melhorar as imagens de qualidade de seus produtos envolvem substituir o acabamento em plástico por vidro ou metal (o que não altera em nada o desempenho do aparelho) ou até mesmo tornar as embalagens mais bonitas. Essas estratégias, apesar de não "melhorarem" os aparelhos, os fazem parecer mais "premium", o que faz com que o consumidor interprete a compra como de um artigo mais luxuoso.

\subsection{Sugestões para estudos futuros}

Para futuros trabalhos e estudos que tratem de atitude e percepção dos consumidores em relação a smartphones chineses, recomenda-se trabalhar com um público-alvo mais diverso. Dos 147 respondentes na etapa quantitativa da pesquisa, $74,8 \%$ não tinham um smartphone de marca chinesa e 6,8\% não souberam responder de onde era a marca de seu telefone. Seria interessante que as próximas pesquisas sobre 0 assunto trabalhassem com um número maior de usuários de celulares de marcas chinesas.

Seria interessante também que os futuros estudos buscassem explorar as estratégias de marketing e comunicação que as companhias chinesas utilizam e compará-las com suas concorrentes não-chinesas. Essas pesquisas seriam capazes de ir além dos atributos diretamente relacionados aos telefones celulares e buscariam entender se as maneiras pelas quais as empresas chinesas ofertam seus produtos são mais eficientes ou não que as estratégias de empresas como Apple e Samsung. 


\section{Referências Bibliográficas}

BAPTISTA, D. Um ano de Xiaomi no Brasil: adequação tornou empresa mais cara que a Apple | Opinião. [S. I.], 5 jun. 2020. Disponível em: https://www.tudocelular.com/android/noticias/n157828/um-ano-xiaomi-no-brasilcusto-beneficio-opiniao.html. Acesso em: 21 out. 2020.

BBC NEWS MUNDO. Por que governo da Lituânia fez alerta contra uso de celulares chineses. [S. I.], 23 set. 2021. Disponível em: https://www.bbc.com/portuguese/internacional-58659707. Acesso em: 26 out. 2021.

CANALYS. Xiaomi beats Samsung to become top smartphone vendor in India. [S. I.], 24 jan. 2018. Disponível em:

https://www.canalys.com/newsroom/xiaomi-beats-samsung-become-topsmartphone-vendor-india. Acesso em: 17 out. 2020.

GIL, Antonio Carlos. Métodos e Técnicas de Pesquisa Social. 6. ed. São Paulo: Atlas, 2008. ISBN 9788522451425.

GREEN, M; KEEGAN, W. Global Marketing. 9. ed. [S. I.]: Pearson, 2016 Capítulo 10

HESLOP, L; PAPADOPOULOS, N. Country equity and country branding: Problems and prospects. Henry Stewart Publications: Brand Management, [s. I.], v. 9, p. 294-314, 2002.

HESLOP, L; PAPADOPOULOS, N. Product-country Images: Impact and Role in International Marketing. [S. I.: s. n.], 1993.

KATES, Steven. A Qualitative Exploration into Voters' Ethical Perceptions of Political Advertising: Discourse, Disinformation, and Moral Boundaries. Journal of Business Ethics, [s. I.], 1998. Disponível em: https://link.springer.com/article/10.1023/A:1005796113389. Acesso em: 13 out. 2021.

MALHOTRA, Naresh. Pesquisa de Marketing: Foco na decisão. 3. ed. [S. I.]: Pearson Education do Brasil, 2011. ISBN 9788576058878. 
MANSERA, A. Os celulares mais vendidos no Brasil e no mundo. [S. I.], 3 set. 2020. Disponível em: https://mobizoo.com.br/opiniao/celulares-maisvendidos/. Acesso em: 17 out. 2020.

SZMIGIERA, M. Working time required to buy an iPhone in cities worldwide 2018. [S. I.], 30 jun. 2021. This statistic shows the average working time required to buy one iPhone X (64GB) in selected cities around the world in 2018. In Cairo, the average worker had to work for about $1,066.2$ hours to be able to purchase an iPhone X. Disponível em: https://www.statista.com/statistics/275243/iphoneworldwide-cities-working-time/. Acesso em: 27 out. 2021.

SOLOMON, Michael R. O Comportamento do Consumidor: Comprando, possuindo e sendo; tradução Beth Honorato - 11 ed. Porto Alegre: Bookman, 2016 - Capítulos 5 e 8.

STATCOUNTER. Mobile Vendor Market Share Brazil: Mar 2010 - Sept 2020. [S. I.], 2020. Disponível em: https://gs.statcounter.com/vendor-marketshare/mobile/brazil/\#monthly-201003-202009. Acesso em: 21 out. 2020.

TAO, Li; DAI, Sarah. Behind the rise of China's smartphone brands lies growing unease over country's tech gains. [S. I.], 30 jan. 2019. Disponível em: https://www.scmp.com/tech/gear/article/2184131/behind-rise-chinas-smartphonebrands-lies-growing-unease-over-countrys. Acesso em: 21 out. 2020.

TIEYING, M. Chart of the Week: Behind the rise of Chinese smartphone makers. [S. I.], 11 fev. 2019. Disponível em:

https://www.dbs.com/aics/templatedata/article/generic/data/en/GR/022019/19021 1_economics_chart_of_the_week.xml. Acesso em: 17 out. 2020.

VANI, Samir. 0 "novo normal" no preço dos smartphones. [S. I.], 26 ago. 2020. Disponível em: https://canaltech.com.br/produtos/o-novo-normal-no-precodos-smartphones/. Acesso em: 16 out. 2021. 


\section{Apêndices}

\section{Apêndice 1}

\section{Entrevistado 1}

Idade: $\mathbf{3 0}$

\section{Engenheiro}

1. Na sua opinião, o que um telefone precisa ter para ser considerado de qualidade?

R: Câmera boa, responsividade, tela grande.

a. O que você acha da qualidade do seu telefone como um todo?

R: Boa.

2. Para você, quando que um telefone pode ser considerado barato ou caro?

R: Eu sempre comparo com a qualidade dele, então complica, mas acho que abaixo de $R \$ 800,00$ é incontestavelmente barato e acima de $R \$ 2000,00$ é incontestavelmente caro.

a. Qual é a sua avaliação do Custo x Benefício do seu telefone? Você diria que o seu telefone é barato ou caro em relação aos benefícios que ele oferece?

R: Justo.

3. O que faz você achar que um telefone é bonito ou feio?

R: Eu acho que nunca achei um telefone verdadeiramente feio.

a. Você acha o seu telefone bonito ou feio? O que você acha do acabamento do seu telefone?

R: Bonito.

4. O que faz você achar que a qualidade da câmera de um telefone é boa ou ruim?

$\mathrm{R}$ : A foto não sair tremida com pouco esforço, mesmo com baixa iluminação e resolução boa.

a. O que você acha da qualidade da câmera do seu telefone?

R: Ruim.

5. O que faz você achar que a qualidade do áudio de um telefone é boa ou ruim?

R: Quantidade de frequências e ausência de ruído. 
a. O que você acha da qualidade do áudio do seu telefone?

R: Ok; boa.

6. Você sabia que a marca do seu telefone é chinesa?

$\mathrm{R}: \mathrm{Sim}$.

a. Quais os sentimentos que você tem em relação a produtos vindos da China?

R: Relação positiva.

b. O que você acha da qualidade de celulares de marcas chinesas ou vindos da China?

R: Boa.

c. Você recomenda a outras pessoas comprarem celulares vindos da China?

R: Sim.

7. O que você associa com a palavra "smartphone"?

$\mathrm{R}$ : Touchscreen, OS nessa vibe de aplicativos, acesso a internet.

8. Quais marcas você associa à palavra "smartphone"?

R: Apple, Motorola, Xiaomi, Huawei, Oneplus, Google, Sony, Oppo, Asus.

9. O que você associa quando pensa na marca do seu celular?

R: Que ou todo mundo reclama a toa ou eu dou muita sorte.

10. Quais fatores você diria que diferenciam o seu telefone dos de outras marcas?

R: Ótimo custo benefício.

11. O que, no seu celular, mais chama a sua atenção?

R: Biometria sob a tela.

\section{Entrevistado 2}

Idade: 26

\section{Estudante de design}

1. Na sua opinião, o que um telefone precisa ter para ser considerado de qualidade?

R: Não ficar travando. Ser compatível com aplicativos. Durar mais de 2 3 anos rodando bem. Responsividade. Câmera boa é ok, mas hoje em dia qualquer celular vem com uma câmera q ja ta mais do q boa. Um diferencial que eu procuro em celulares também é não ter app de fábrica que você não pode deletar.

a. O que você acha da qualidade do seu telefone como um todo?

R: Meu celular é um Mi A2. Comprei ele sabendo que ele não era o melhor que tinha, até pq tava pra sair já o Mi A3. Me arrependo um pouco de ter comprado 
ele, pois tinha condição de ter comprado o Mi9t, q tava saindo, mas preferi economizar.

2. Para você, quando que um telefone pode ser considerado barato ou caro?

R: Eu vejo por comparativo. Mas pra mim qualquer celular é caro, qualquer celular acima de $R \$ 1.000,00$ pra mim vai ser caro. Acima de $R \$ 2.000,00$ eu já começo a me perguntar se realmente vale a pena, mesmo se ele for bom. Acima de $R \$$ $3.000,00$ é não.

a. Qual é a sua avaliação do Custo x Benefício do seu telefone? Você diria que o seu telefone é barato ou caro em relação aos benefícios que ele oferece?

$\mathrm{R}$ : Na época achei barato, mas não lembro se estava em promoção.

3. O que faz você achar que um telefone é bonito ou feio?

R: Pra mim todo celular é igual, então não tem muito isso de feio e bonito. Pra mim, celular bonito é celular flip.

a. Você acha o seu telefone bonito ou feio? O que você acha do acabamento do seu telefone?

R: É igual a qualquer outro, eu acho.

4. O que faz você achar que a qualidade da câmera de um telefone é boa ou ruim?

R: Se a câmera tem mais de $10 \mathrm{mp}$, a câmera vai ser boa. A partir daí, a resolução não importa, mas sim a Al que vem junto, e as capacidades dela.

a. O que você acha da qualidade da câmera do seu telefone?

R: Razoável

5. O que faz você achar que a qualidade do áudio de um telefone é boa ou ruim? $\mathrm{R}$ : Bota bohemian rhapsody no max e vê se distorce a música. Se não distorce muito, tá bom (sempre vai distorcer porque a caixinha de som pequena sempre vai ser um pouco pior).

a. O que você acha da qualidade do áudio do seu telefone?

R: Acho ok.

6. Você sabia que a marca do seu telefone é chinesa?

R: Sim

a. Quais os sentimentos que você tem em relação a produtos vindos da China?

R: Depende. Os softwares eu não gosto tanto assim porque eles fazem algumas coisas de forma meio porca. Os hardwares em geral são bem bons.

b. O que você acha da qualidade de celulares de marcas chinesas ou vindos da China?

R: Em geral são bem bons, quando não tentam fazer o próprio OS. 
c. Você recomenda a outras pessoas comprarem celulares vindos da China?

R: Se a pessoa quer um Android, sim.

7. O que você associa com a palavra "smartphone"?

R: Touchscreen, acesso a internet. Apps (muitos apps, tudo é app hoje em dia).

Conectividade com outros aparelhos.

8. Quais marcas você associa à palavra "smartphone"?

R: Apple, Samsung, Xiaomi, LG, Huawei, Motorola, Lenovo (de cabeça é isso).

9. O que você associa quando pensa na marca do seu celular?

R: Celular e China.

10. Quais fatores você diria que diferenciam o seu telefone dos de outras marcas?

R: Se comparado a Apple, ele é um Android. Se comparado aos outros Androids, não há muita coisa. Ele usa um Android mais puro do que Samsung e Motorola, mas fora isso, acho que o preço.

11. O que, no seu celular, mais chama a sua atenção?

R: Nada demais. Ele é um aparelho ok pelo preço, e vem com Android, que era o que eu queria.

\section{Entrevistado 3}

\section{Idade: 26}

\section{Economista}

1. Na sua opinião, o que um telefone precisa ter para ser considerado de qualidade?

R: Bateria boa, armazenamento bom, bons aplicativos, câmera boa e imagem boa.

a. O que você acha da qualidade do seu telefone como um todo?

R: Mediano.

2. Para você, quando que um telefone pode ser considerado barato ou caro?

$\mathrm{R}$ : Acima de $\mathrm{R} \$ 2.000,00$ está caro.

a. Qual é a sua avaliação do Custo x Benefício do seu telefone? Você diria que o seu telefone é barato ou caro em relação aos benefícios que ele oferece?

$\mathrm{R}$ : Justo.

3. O que faz você achar que um telefone é bonito ou feio?

$\mathrm{R}$ : Tamanho (quanto mais grosso mais feio) e cor.

a. Você acha o seu telefone bonito ou feio? O que você acha do acabamento do seu telefone?

R: Ok. 
4. O que faz você achar que a qualidade da câmera de um telefone é boa ou ruim?

R: Fidelidade à realidade, foco e zoom.

a. O que você acha da qualidade da câmera do seu telefone?

R: Ruim.

5. O que faz você achar que a qualidade do áudio de um telefone é boa ou ruim?

R: O quão estourado é o som, o quão alto o usuário consegue colocar.

a. O que você acha da qualidade do áudio do seu telefone?

R: Boa

6. Você sabia que a marca do seu telefone é chinesa?

R: Não

a. Quais os sentimentos que você tem em relação a produtos vindos da China?

R: Negativos, dependendo do produto.

b. O que você acha da qualidade de celulares de marcas chinesas ou vindos da China?

R: São ok.

C. Você recomenda a outras pessoas comprarem celulares vindos da China? R: Sim.

7. O que você associa com a palavra "smartphone"?

$\mathrm{R}$ : Praticidade, tecnologia moderna

8. Quais marcas você associa à palavra "smartphone"?

R: Apple, Motorola, Samsung, huawei

9. O que você associa quando pensa na marca do seu celular?

R: Alternativa com bom custo benefício

10. Quais fatores você diria que diferenciam o seu telefone dos de outras marcas?

R: Mais intuitivo e tamanho prático

11. O que, no seu celular, mais chama a sua atenção?

$\mathrm{R}$ : Tamanho, bateria ruim e responsividade ruim.

\section{Entrevistado 4}

Idade 50:

Professor 
1. Na sua opinião, o que um telefone precisa ter para ser considerado de qualidade?

R: Deve ser rápido, facilidade de acesso; intuitivo, tela boa.

a. O que você acha da qualidade do seu telefone como um todo?

R: Boa.

2. Para você, quando que um telefone pode ser considerado barato ou caro?

R: Comparação feita sempre com iPhone.

a. Qual é a sua avaliação do Custo x Benefício do seu telefone? Você diria que o seu telefone é barato ou caro em relação aos benefícios que ele oferece?

R: Preço justo.

3. O que faz você achar que um telefone é bonito ou feio?

R: Telefones muito robustos são feios; finura, peso.

a. Você acha o seu telefone bonito ou feio? O que você acha do acabamento do seu telefone?

R: Nem bonito nem feio.

4. O que faz você achar que a qualidade da câmera de um telefone é boa ou ruim?

R: Foco automático, nitidez da imagem.

a. O que você acha da qualidade da câmera do seu telefone?

R: Média.

5. O que faz você achar que a qualidade do áudio de um telefone é boa ou ruim? R: Som claro, sem ruídos.

a. O que você acha da qualidade do áudio do seu telefone?

R: Médio.

6. Você sabia que a marca do seu telefone é chinesa?

$\mathrm{R}: \mathrm{Sim}$.

a. Quais os sentimentos que você tem em relação a produtos vindos da China?

$\mathrm{R}$ : Boa qualidade e preços bons.

b. O que você acha da qualidade de celulares de marcas chinesas ou vindos da China?

R: Bons, porém não fantásticos. Bom custo benefício.

c. Você recomenda a outras pessoas comprarem celulares vindos da China?

R: Sim.

7. O que você associa com a palavra "smartphone"? 
R: Praticidade.

8. Quais marcas você associa à palavra "smartphone"?

R: Samsung, Motorola e Apple.

9. O que você associa quando pensa na marca do seu celular?

R: Bom custo benefício.

10. Quais fatores você diria que diferenciam o seu telefone dos de outras marcas?

R: O preço.

11. O que, no seu celular, mais chama a sua atenção?

R: Nada.

\section{Entrevistado 5}

Idade: 26

\section{Administrador}

1. Na sua opinião, o que um telefone precisa ter para ser considerado de qualidade?

R: Uma boa bateria, câmera decente, tela com textura lisa que o touch "desliza" bem (tem umas que parece que são tão engorduradas, o dedo agarra, o touch não desliza), sistema operacional simples (detesto quando tem mil "atalhos" de gesto que na verdade o celular só funciona direito se você fizer eles todos e tem uns que interagem mal com outros usos que você vai fazer do celular e é horrível).

a. O que você acha da qualidade do seu telefone como um todo?

R: Boa

2. Para você, quando que um telefone pode ser considerado barato ou caro?

$R$ : Abaixo de $R \$ 750,00$ é barato para qualquer nível e acima de $R \$ 2.000,00$ é caro para qualquer nível (nenhum celular entrega o suficiente para mais que isso valer a pena).

a. Qual é a sua avaliação do Custo x Benefício do seu telefone? Você diria que o seu telefone é barato ou caro em relação aos benefícios que ele oferece?

R: Meu celular foi 1500 e eu acho ele excelente. Tendo caixa para comprar ele, acho que o custo benefício compensa sim.

3. O que faz você achar que um telefone é bonito ou feio?

R: Em geral, celular é tudo igual: retangular com uma tela do tamanho dele todo. Alguns inventam moda e poem umas adições feias sim, tipo aquelas câmeras da Apple que dão tripofobia na galera. De resto, tudo igual e todo mundo vai botar capinha mesmo, nem que seja pra proteger, então o que conta é a tela. 
a. Você acha o seu telefone bonito ou feio? O que você acha do acabamento do seu telefone?

R: Meu celular não tem nenhuma doideira adicional que deixe ele feio, então vou dizer bonito. Acabamento eu diria que normal? Nunca vi acabamento ruim em celular, sei nem como seria.

4. O que faz você achar que a qualidade da câmera de um telefone é boa ou ruim?

R: Lidar bem com diferentes iluminações e com movimento, e foco. Imagens nítidas com muito sol ou pouca luz. Imagens nítidas quando o objeto da fotografia está mexendo ou quando eu tô segurando o celular com uma mão só e rola aquela tremedeira.

a. O que você acha da qualidade da câmera do seu telefone?

R: Razoável.

5. O que faz você achar que a qualidade do áudio de um telefone é boa ou ruim? R: Da caixinha de som? É sempre ruim. Não conheço um único com áudio bom. Quem não tem caixinha tá ferrado e ponto. Talvez um dia a qualidade possa ser razoável se: 1. Der pra ouvir os graves; 2 . Os agudos não ficarem estridentes. Por enquanto, nunca vi um celular capaz disso.

Agora, se for da ligação, contanto que dê pra ouvir a pessoa do outro lado tá valendo.

a. O que você acha da qualidade do áudio do seu telefone?

R: Caixinha de som tão ruim quanto o menos pior pode ser, mas ainda não uso se puder evitar. Ligação não tenho reclamações então diria que boa.

6. Você sabia que a marca do seu telefone é chinesa?

R: Sim

a. Quais os sentimentos que você tem em relação a produtos vindos da China?

R: Irrelevante. Tudo vem de lá mesmo, independente da nacionalidade da marca. Acho hipócrita comprar tudo produzido na China, mas traçar a linha na nacionalidade da marca só.

b. O que você acha da qualidade de celulares de marcas chinesas ou vindos da China?

R: A mesma qualidade de produtos de marcas não-Chinesas que também vêm da China. Nunca ouvi falar de um não chinês e não vindo da China, então nem que quisesse dava para comparar.

c. Você recomenda a outras pessoas comprarem celulares vindos da China?

$\mathrm{R}$ : Se a pessoa quiser uma recomendação de celular, qualquer uma que eu dê vai ser vinda da China. Mas em termos de marca chinesa, sim. Eu sempre recomendo Motorola.

7. O que você associa com a palavra "smartphone"? 
R: Touch Screen, aplicativos, internet.

8. Quais marcas você associa à palavra "smartphone"?

R: Motorola, Xiaomi, Samsung, Asus, Apple

9. O que você associa quando pensa na marca do seu celular?

R: O toque "hello moto" (sério, é a única coisa que passa no meu cérebro de associação direta e imediata).

10. Quais fatores você diria que diferenciam o seu telefone dos de outras marcas? $\mathrm{R}$ : $\mathrm{O}$ android dele é bem bom, a bateria dura pra lá de dois dias em uso médio e quase um dia inteiro de uso intenso (tela o tempo todo ligada jogando jogo e ouvindo música no fone).

11. O que, no seu celular, mais chama a sua atenção?

R: Bateria.

\section{Entrevistado 6}

Idade: $\mathbf{4 1}$

\section{Diarista}

1. Na sua opinião, o que um telefone precisa ter para ser considerado de qualidade?

R: Câmera boa, memória grande, tela de alta resolução.

a. O que você acha da qualidade do seu telefone como um todo?

R: Ruim.

2. Para você, quando que um telefone pode ser considerado barato ou caro?

$\mathrm{R}: \mathrm{R} \$ 800,00-\mathrm{R} \$ 1.500,00$ barato; $\mathrm{R} \$ 1.500,00$ - ... caro.

a. Qual é a sua avaliação do Custo $\times$ Benefício do seu telefone? Você diria que o seu telefone é barato ou caro em relação aos benefícios que ele oferece?

R: Barato.

3. O que faz você achar que um telefone é bonito ou feio?

R: O padrão de beleza da sua época.

a. Você acha o seu telefone bonito ou feio? O que você acha do acabamento do seu telefone?

R: Feio.

4. O que faz você achar que a qualidade da câmera de um telefone é boa ou ruim?

R: A câmera é boa quando: imagem em alta resolução e cores fiéis à realidade.

a. O que você acha da qualidade da câmera do seu telefone?

R: Péssima. 
5. O que faz você achar que a qualidade do áudio de um telefone é boa ou ruim?

$\mathrm{R}$ : Som sem ruídos e fiel à realidade.

a. O que você acha da qualidade do áudio do seu telefone?

R: Péssimo.

6. Você sabia que a marca do seu telefone é chinesa?

R: Não.

a. Quais os sentimentos que você tem em relação a produtos vindos da China?

R: Em geral, acho que os produtos são bons.

b. O que você acha da qualidade de celulares de marcas chinesas ou vindos da China?

R: Boa qualidade.

C. Você recomenda a outras pessoas comprarem celulares vindos da China?

$\mathrm{R}: \mathrm{Sim}$.

7. O que você associa com a palavra "smartphone"?

R: Um telefone bom, de alta qualidade.

8. Quais marcas você associa à palavra "smartphone"?

R: Motorola e Samsung.

9. O que você associa quando pensa na marca do seu celular?

$\mathrm{R}$ : Telefones.

10. Quais fatores você diria que diferenciam o seu telefone dos de outras marcas?

R: Confio na marca, uma vez que já tive outros. Preço bom em relação às outras marcas.

11. O que, no seu celular, mais chama a sua atenção?

$\mathrm{R}$ : A bateria dura muito pouco.

\section{Entrevistado 7}

Idade: 24

\section{Auxiliar de escritório}

1. Na sua opinião, o que um telefone precisa ter para ser considerado de qualidade?

R: Boa duração de bateria, boa memória interna e boa capacidade de extensão de memória, ter uma câmera razoável e processador bom.

a. O que você acha da qualidade do seu telefone como um todo?

R: Muito boa. 
2. Para você, quando que um telefone pode ser considerado barato ou caro? R: Por volta de mil reais e com as coisas que eu respondi na primeira questão é barato ou preço razoável, acima de $R \$ 1.500$ independentemente do que ele ofereça, é caro pra mim.

a. Qual é a sua avaliação do Custo x Benefício do seu telefone? Você diria que o seu telefone é barato ou caro em relação aos benefícios que ele oferece? R: Barato

3. O que faz você achar que um telefone é bonito ou feio?

Cor principalmente, mas se o formato dele não for muito quadradão, cheio de bordas também ajuda

a. Você acha o seu telefone bonito ou feio? O que você acha do acabamento do seu telefone?

$\mathrm{R}$ : Bonito, e muito bom. Só acho que poderiam ter pensado na proteção da câmera, porque eu tenho cinco câmeras e fica um negócio imenso pra fora, se eu não estiver usando capinha o telefone não fica reto em cima da mesa, por exemplo.

4. O que faz você achar que a qualidade da câmera de um telefone é boa ou ruim?

$\mathrm{R}$ : Principalmente em como ela captura coisas em movimento e a facilidade dela focar nas coisas, fora isso não sei porque não uso muito.

a. O que você acha da qualidade da câmera do seu telefone?

$\mathrm{R}$ : Muito boa.

5. O que faz você achar que a qualidade do áudio de um telefone é boa ou ruim?

R: Se captura a voz limpa, sem interferência de ruídos externos e se a voz fica natural.

a. O que você acha da qualidade do áudio do seu telefone?

R: Não sei, não presto muita atenção, mas deve ser bom.

6. Você sabia que a marca do seu telefone é chinesa?

$\mathrm{R}: \mathrm{Sim}$.

a. Quais os sentimentos que você tem em relação a produtos vindos da China?

$\mathrm{R}$ : Amo, sou a propagadora da palavra do gearbest, aliexpress e etc, nos domingos de manhã eu bato na porta das pessoas e mando elas comprarem celulares chineses porque vale mais a pena.

b. O que você acha da qualidade de celulares de marcas chinesas ou vindos da China? 
R: Muito boa.

C. Você recomenda a outras pessoas comprarem celulares vindos da China? R: Sim.

7. O que você associa com a palavra "smartphone"?

R: Celular.

8. Quais marcas você associa à palavra "smartphone"?

R: Samsung, Motorola, Xiaomi, Apple, Infinix.

9. O que você associa quando pensa na marca do seu celular?

$\mathrm{R}$ : A caixa prateada.

10. Quais fatores você diria que diferenciam o seu telefone dos de outras marcas?

R: Custo x Benefício.

11. O que, no seu celular, mais chama a sua atenção?

R: As câmeras, é um losango gigante cheio de buraco.

\section{Entrevistado 8 \\ Idade 23 \\ Estudante de jornalismo}

1. Na sua opinião, o que um telefone precisa ter para ser considerado de qualidade?

R: Acredito que a maioria dos recursos que são indispensáveis hoje em dia, todos de preferência. Como estamos cada vez mais dependentes da tecnologia, o telefone precisa corresponder. A questão do tempo de resposta do aparelho é fundamental, por exemplo. Além disso, boa memória e duração da bateria são essenciais.

a. O que você acha da qualidade do seu telefone como um todo?

R: Eu comprei esse Motorola por emergência, porque tinha um outro anteriormente do qual gostava bastante, mas acabei danificando. Ainda que tenha optado por um modelo que fosse mais em conta, porque não planejava mudar de telefone na época, fiquei mais insatisfeito do que satisfeito. Não recomendaria.

2. Para você, quando que um telefone pode ser considerado barato ou caro? $\mathrm{R}$ : Acredito que vai muito da capacidade financeira de cada um. Mas tendo o salário-mínimo como base, e essa me parece uma boa régua, todos os telefones com uma boa qualidade são caros hoje em dia. Há alguns modelos baratos, é verdade, mas é aquele "barato que sai caro".

a. Qual é a sua avaliação do Custo x Benefício do seu telefone? Você diria que o seu telefone é barato ou caro em relação aos benefícios que ele oferece? 
R: Eu não acho que o custo-benefício seja dos melhores. Acredito que, no fim, o preço dele foi razoável pensando nos benefícios, mas poderia ser melhor.

3. O que faz você achar que um telefone é bonito ou feio?

$\mathrm{R}$ : Como, hoje em dia, todos usamos capas de proteção nos celulares, acabo não prestando muita atenção nessa parte estética. Não me lembro de ter comprado um telefone por isso. Mas eu gosto de modelos mais neutros, na cor preta, que não tenham um tamanho exagerado e as bordas não sejam tão "quadradas".

a. Você acha o seu telefone bonito ou feio? O que você acha do acabamento do seu telefone?

R: Acho ele bem bonito. Ele tem um acabamento bem neutro, com detalhes simples. E eu gosto disso. Na verdade, com relação à cor, por exemplo, tive que conferir, pois não uso ele sem capa; de modo que a capa acaba fazendo parte da visão que tenho dele.

4. O que faz você achar que a qualidade da câmera de um telefone é boa ou ruim?

R: Quanto mais nítida a imagem, melhor. Mas vai da necessidade de cada um. No geral, acredito que a qualidade da câmera da maioria dos modelos mais conhecidos são muito boas. Às vezes, é mais uma questão de saber usar esse recurso. Por exemplo, quando usamos o modo automático, os ajustes feitos pela própria câmera podem não ser os melhores.

a. O que você acha da qualidade da câmera do seu telefone?

$\mathrm{R}$ : Eu a considero relativamente boa. O telefone me entrega o que espero dele nesse sentido. Nada muito extraordinário, mas suficiente.

5. O que faz você achar que a qualidade do áudio de um telefone é boa ou ruim?

R: A primeira coisa na qual penso é o volume. Alguns celulares não tem uma boa saída de som, e isso atrapalha bastante.

a. O que você acha da qualidade do áudio do seu telefone?

R: Eu acho que não é tão boa, já que é um pouco baixo. Não é algo que me atrapalhe no dia a dia, mas poderia ser melhor.

6. Você sabia que a marca do seu telefone é chinesa?

R: Eu não sabia. Mas é uma informação interessante. Por algum motivo, pensava que seria da Europa, Coreia do Sul ou Japão.

a. Quais os sentimentos que você tem em relação a produtos vindos da China?

$\mathrm{R}$ : Acho que ainda há uma visão preconceituosa com relação aos produtos chineses. $E$ talvez tenha sido por isso que descobrir que o meu telefone é de uma marca chinesa tenha sido uma grande surpresa. A Motorola talvez não gostasse dessa associação que fazemos no Ocidente. Particularmente, não tenho 
problemas com produtos chineses. Hoje, inclusive, acredito que exista um movimento que vai de encontro com essa visão preconceituosa sobre eles. A gente vê a Xiaomi ganhando muito espaço e credibilidade, e todos sabem que ela é da China.

b. O que você acha da qualidade de celulares de marcas chinesas ou vindos da China?

$\mathrm{R}$ : Acredito que depende da marca. Sem dúvida devem existir marcas ruins, que não conheço ou não sei que são chinesas, mas também existem boas opções, como a Xiaomi. Acho que a questão da origem, quando se trata de uma empresa que produz na China, não interfere muito na qualidade, já que o local é escolhido pelas empresas tendo em mente, sobretudo, os custos de fabricação. Acho que o padrão de qualidade das grandes empresas ajuda bastante nesse sentido

c. Você recomenda a outras pessoas comprarem celulares vindos da China? $\mathrm{R}$ : Recomendo sim, mas sempre tendo em vista a marca do telefone.

7. O que você associa com a palavra "smartphone"?

R: Aplicativos. Muitos. E que respondem de forma praticamente instantânea. A palavra me passa uma sensação de praticidade.

8. Quais marcas você associa à palavra "smartphone"?

R: Samsung e Apple. Essas são as que vêm à minha cabeça rapidamente. Depois, Motorola e Xiaomi.

9. O que você associa quando pensa na marca do seu celular?

R: Sem dúvidas o modelo Razr. Assim como o ringtone "Hello Moto" e a logo. Agora, também penso na China e no Xiaomi, que está roubando o espaço que era da Motorola no Brasil a meu ver.

10. Quais fatores você diria que diferenciam o seu telefone dos de outras marcas?

R: Acho que o preço acaba sendo o fator mais influente. A Motorola é uma marca com uma variedade de preços bem grandes. E outras marcas, que não são tão populares, não tem esse leque. Por exemplo: a Apple tem um público-alvo bem mais segmentado, e isso faz com que não haja uma variedade tão grande de preços.

11. O que, no seu celular, mais chama a sua atenção?

R: Gosto do layout dele. Acho bastante confortável, simples e intuitivo.

\section{Entrevistado 9}

Idade 56

Professor

1. Na sua opinião, o que um telefone precisa ter para ser considerado de qualidade?

R: Funcionamento perfeito. 
a. O que você acha da qualidade do seu telefone como um todo?

R: Boa.

2. Para você, quando que um telefone pode ser considerado barato ou caro? $\mathrm{R}$ : Acima de $\mathrm{R} \$ 1.500,00$ é caro.

a. Qual é a sua avaliação do Custo x Benefício do seu telefone? Você diria que o seu telefone é barato ou caro em relação aos benefícios que ele oferece? R: Barato.

3. O que faz você achar que um telefone é bonito ou feio?

$\mathrm{R}$ : $\mathrm{O}$ design e o que oferece.

a. Você acha o seu telefone bonito ou feio? O que você acha do acabamento do seu telefone?

R: Bonito, mas hoje há mais bonitos.

4. O que faz você achar que a qualidade da câmera de um telefone é boa ou ruim?

R: Qualidade da imagem.

a. O que você acha da qualidade da câmera do seu telefone?

R: Boa.

5. O que faz você achar que a qualidade do áudio de um telefone é boa ou ruim?

R: Potência do volume.

a. O que você acha da qualidade do áudio do seu telefone?

R: Média.

6. Você sabia que a marca do seu telefone é chinesa?

R: Sim.

a. Quais os sentimentos que você tem em relação a produtos vindos da China?

R: Desconfiança.

b. O que você acha da qualidade de celulares de marcas chinesas ou vindos da China?

R: Boa.

C. Você recomenda a outras pessoas comprarem celulares vindos da China? R: Sim. 
7. O que você associa com a palavra "smartphone"?

$\mathrm{R}$ : Telefone de alta tecnologia.

8. Quais marcas você associa à palavra "smartphone"?

R: Samsung e Motorola.

9. O que você associa quando pensa na marca do seu celular?

R: Praticidade.

10. Quais fatores você diria que diferenciam o seu telefone dos de outras marcas?

R: Custo X Benefício.

11. O que, no seu celular, mais chama a sua atenção?

R: O tamanho.

Entrevistado 10

Idade 32

Advogado

1. Na sua opinião, o que um telefone precisa ter para ser considerado de qualidade?

R: Não pode ser muito frágil, bateria de longa duração, câmera de qualidade, armazenamento bom e processador bom.

a. O que você acha da qualidade do seu telefone como um todo?

R: Ruim.

2. Para você, quando que um telefone pode ser considerado barato ou caro?

$R$ : Acima de $R \$ 2.000,00$ é caro.

a. Qual é a sua avaliação do Custo x Benefício do seu telefone? Você diria que o seu telefone é barato ou caro em relação aos benefícios que ele oferece?

R: Justo.

3. O que faz você achar que um telefone é bonito ou feio?

$\mathrm{R}$ : Cor e posição das câmeras traseiras.

a. Você acha o seu telefone bonito ou feio? O que você acha do acabamento do seu telefone?

R: Feio.

4. O que faz você achar que a qualidade da câmera de um telefone é boa ou ruim? 
R: Qualidade da imagem e fidelidade à realidade.

a. O que você acha da qualidade da câmera do seu telefone?

R: Ruim.

5. O que faz você achar que a qualidade do áudio de um telefone é boa ou ruim? $\mathrm{R}$ : É ruim quando o áudio é estourado e a distorção do som é grande.

a. O que você acha da qualidade do áudio do seu telefone?

R: Ok.

6. Você sabia que a marca do seu telefone é chinesa?

R: Sim.

a. Quais os sentimentos que você tem em relação a produtos vindos da China?

R: Desconfiança.

b. O que você acha da qualidade de celulares de marcas chinesas ou vindos da China?

R: Há alguns anos atrás eram ruins. Hoje são bastante competitivos.

c. Você recomenda a outras pessoas comprarem celulares vindos da China?

R: Hoje sim

7. O que você associa com a palavra "smartphone"?

$\mathrm{R}$ : Telefone com acesso à internet, tela touch e aplicativos.

8. Quais marcas você associa à palavra "smartphone"?

R: Apple, Samsung, Google, Motorola, Huawei.

9. O que você associa quando pensa na marca do seu celular?

$\mathrm{R}$ : Marca antiga no mercado, pouco competitiva entre os melhores telefones, porém se tornando bastante popular.

10. Quais fatores você diria que diferenciam o seu telefone dos de outras marcas?

R: Bom custo benefício e confiabilidade na marca.

11. O que, no seu celular, mais chama a sua atenção?

R: Câmera ruim. 


\section{Apêndice 2}

\section{Etapa Quantitativa}

\section{1' Parte}

1) A marca do seu telefone é chinesa?

- $\operatorname{Sim}$

- Não

- Não sei

2) Em relação ao seu smartphone, o que você acha da qualidade da sua câmera?
- 1
- 2
- 3
- 4
- 5
- 6
- 7
- 8
- 9
- 10

3) Em relação ao seu smartphone, o que você acha da duração da bateria?
- 1
- 2
- 3
- 4
- 5
- 6
- 7
- 8
- 9 
- 10

4) Em relação ao seu smartphone, o que você acha do seu design?
- 1
- 2
- 3
- 4
- 5
- 6
- 7
- 8
- 9
- 10

5) Em relação ao seu smartphone, o que você acha do seu Custo $x$ Benefício?
- 1
- 2
- 3
- 4
- 5
- 6
- 7
- 8
- 9
- 10

6) Como você avaliaria esses atributos em grau de importância? (1 sendo o menos importante e 4 o mais importante)

- Câmera

- Bateria

- Design

- Custo x Benefício
1234

1234

1234

1234 


\section{2- Parte}

7) Em relação aos diferentes smartphones disponíveis no mercado, qual nota você acha que reflete a qualidade da câmera das seguintes marcas (sendo 1 a pior nota e 10 a melhor):

- iPhone

- Samsung

- Xiaomi
12345678910

12345678910

12345678910

ou outra marca chinesa que você conheça

8) Em relação aos diferentes smartphones disponíveis no mercado, qual nota você acha que reflete a duração da bateria dos celulares das seguintes marcas (sendo 1 a pior nota e 10 a melhor):

- iPhone

- Samsung

- Xiaomi
12345678910

12345678910

123456678910

ou outra marca chinesa que você conheça

9) Em relação aos diferentes smartphones disponíveis no mercado, qual nota você acha que reflete o design dos celulares das seguintes marcas (sendo 1 a pior nota e 10 a melhor):

- iPhone

- Samsung

- Xiaomi
12345678910

123456789910

12345678910

ou outra marca chinesa que você conheça

10) Em relação aos diferentes smartphones disponíveis no mercado, qual nota você acha que reflete o Custo x Benefício dos celulares das seguintes marcas (sendo 1 a pior nota e 10 a melhor): 
- iPhone

- Samsung

- Xiaomi
12345678910

12345678910

12345678910

ou outra marca chinesa que você conheça 